\title{
Graz - Process and Transformation
}

\section{Graz - procesy a transformace}

Adéla Chroboczková

Ústav urbanismu, Fakulta architektury, Vysoké učení technické v Brně, Česká republika adela.chroboczkova@seznam.cz

\begin{abstract}
This paper focuses on the process of urban transformation of the city of Graz. Some methods that are important in terms of their investigation and possible application can be found in Graz. The methods are based on these programs: Urban, Urban II (Urban_Link Graz - West) and Smart City. As part of these programs, new types of methods and processes were designed for funding, participation, sharing of information, etc. These new methods can be used as a manual on how to deal with this issue in Brno. Some of them are likely to be applied in Brno.
\end{abstract}

KEYWORDS: Graz urbanism; transformation; Smart City; post-industrial city

ABSTRAKT: Článek je zaměřen na urbanistické procesy transformace ve městě Graz. Z nich jsou v rámci novodobých transformačních urbanistických metod významné pro studium a možnou aplikaci u nás ty, které vychází z nejvýznamnějších urbanistických programů Urban, Urban II (Urban_Link Graz - West) a Smart City. Nejde jen o studium samotných programů, ale také zejména procesů, které se v jednotlivých programech projevují, jako financování jednotlivých kroků, participace, komunikace a další podpůrné procesy. Tyto lokality a programy, s jejichž pomocí byly tyto lokality vytvořeny, mohou být nejen inspirací, ale možná i manuálem, jak pracovat s podobnými lokalitami v Brně.

KLÍČOVÁ SLOVA: Graz; urbanismus; transformace; Smart City; postindustriální město 


\section{Úvod}

Graz je město, kde 55 procent občanů jezdí veřejnou dopravou, na kole nebo chodí pěšky. Město, které může být vzorem nejen pro Brno. Je to druhé největší město Rakouska. Jeho rozloha je $127,58 \mathrm{~km}^{2}$ (rozloha Brna je $230 \mathrm{~km}^{2}$ ). Je rozděleno na 17 okrsků (Brno jich má 29). Městem protéká řeka Mur, která jej dělí na dvě části. Graz je univerzitní město se 4 univerzitami. Má 300000 obyvatel a 60000 studentů (Brno má 377000 obyvatel). (Štýrský Hradec, 2015)

Graz roste každým dnem. Vedení města si jasně uvědomuje jeho limity. Proto postupuje pomocí strategických kroků v transformaci území. Jasně se zde projevují prvky Compact city, Smart city a dalších urbanistických trendů současnosti. Transformace začala roku 1950 a trvá až do ted. V rámci novodobých transformačních urbanistických metod jsou významné pro studium a možnou aplikaci u nás ty, které vychází z nejvýznamnějších urbanistických programů Urban, Urban II a Smart City. Nejde jen o studium programů, ale i procesů, které se v nich vyskytují, jako financování jednotlivých kroků, participace, komunikace a další podpůrné procesy.

\section{Stav poznání - historie}

Na město měl vliv průmyslový rozvoj (19. století) a druhá světová válka (každá třetí budova ve městě byla zničena nebo poškozena). V regeneračním územním plánu (90. léta 20. století) dostala řeka úlohu spojit městské části, historickou a chudou část. Muzeum moderního umění - Kunsthaus - se stalo novým symbolem města a Murinsel se stal symbolem propojení. Za zmínku stojí regenerace dopravního uzlu Jakominiplatz (je podobný Mendlovu náměstí v Brně).

První urbanistické programy pochází z let 1989-1993. Nejvýznamnější pro vývoj města byly následující etapy:

- 1995 - vstup do Evropské unie,

- 1999 - historické centrum bylo zapsáno na Seznam světového kulturního a prrírodního dědictví UNESCO,

- 2003 - město se stalo hlavním městem kultury,

- 2011 - Graz se stal členem sítě UNESCO Kreativní města,

- 2011 - Graz se stal Městem designu,

- 2013 - město bylo zařazeno na seznam Smart City.

Díky těmto programům dostalo město velkou část finančních prostředků potřebných k jeho transformaci. Kultura se stala součástí obnovy města. (Arendjelovic, 2015) 


\section{Stav poznání - etapy transformací}

Z hlediska urbanistického tvář novodobého města změnily tři programy či etapy. (Obr. 1)

\section{Urban}

Program Urban (1994-1999) vykazuje znaky Compact city. První transformace začaly v městské části Gries (také nazývané Gürtel Don Bosco), přímo navazující na historický střed. Tato oblast je podobná oblasti Cejl v Brně. Obyvatelstvo lokality Gries je tvořeno z velké části přistěhovalci, kteří představují vzdělanostní, náboženský, etnický a ekonomický mix (11 000 obyvatel).

Jednalo se o projekty zaměřené na zlepšení sociální struktury a na zkvalitnění městského prostoru a zeleně. Rekonstrukce veřejných prostor v souběhu se sociálními projekty byla velmi úspěšná. Důležitou roli hrála aktivní účast občanů a sdílení informací. Byla zde vytvořena webová platforma graz.at/urban. Participace a práce s informacemi jsou jedněmi se základních prvků Smart city. Byla zde aplikována metoda vytvoření sítě sousedství - lidé se mohou vyjadřovat k projektům ve svém okolí a stát se aktivními členy týmu. Celý systém fungoval zdola nahoru. (MAGISTRAT GRAZ, 1998); (Graz West: Ein Stadtteil im Aufbruch, 1998)

\section{Urban II}

Program Urban II (2006-2007) se zaměřoval na plochy v zóně Graz West za nádražím (Bahnhofsviertel) - historicky monofunkční průmyslové zóně, která navazuje na lokalitu Gries. Hlavním problémem bylo propojení této lokality s centrálními oblastmi města, bariéru zde tvořilo drážní těleso. Lokalita je tvořena plochami brownfields a starými průmyslovými objekty. Vedení města si uvědomuje, že je důležité město udržet kompaktním, využívat plochy uvnitř města a nevytvářet městské čtvrti na zelené louce.

Jako motivační projekt byl zvolen projekt kampusu Joanneum, který měl dát lokalitě vizi a směr - rozvoj potenciálu informační společnosti. Dále zde bylo vytvořeno Vědecké centrum a Start-up-Center v bývalé správní budově pivovaru Reinighaus.

Dalším ze směrů, kterými se město řídí, je „udržitelný rozvoj“. Byl zde využit potenciál revitalizace a zrušení bariér (mimoúrovňové kř́ižení dopravy). 
Za zmínku stojí budova Helmut List Halle, která vznikla transformací haly z 19. století na multifunkční koncertní halu, jejíž plášt je na jižní straně pokryt fotovoltaickými články a která je energeticky soběstačná.

Jako komunikační médium byla využita informační platforma Gemeinschaftsinitiative URBAN. V této síti URBAN je 12 německých měst a 2 rakouská města. Pomocí této platformy probíhala a stále probíhá výměna informací.

Aby proces transformace probíhal plynule a rychle, byl použit „řízený proces komunikace“. Bylo zde vytvořeno informační centrum (Urban Box), informační systém (URBAN Stadtteil-Info) a internetové stránky www.urban-link.at. (Urban Graz-West Newsletter der Programmleitung: Newsletter 4, 2005) V této lokalitě se také kladl zvýšený důraz na nové koncepty mobility.

\section{Smart City Graz}

Vývojová etapa Smart City právě probíhá. Pojmem inteligentní město je definováno město, které efektivně hospodaří s energiemi, je nízkoemisní a poskytuje nejvyšší kvalitu života. Je zaměřené na bydlení, práci a volný čas a klade důraz na potřeby na lokální bázi. Významnými stanovišti jsou veřejné prostory a parky. Prioritou je opatrné zacházení s životním prostředím pomocí udržitelných konceptů energetiky, dopravy a plánování.

Pojem Smart city je systém postupů a inovací. Postupy, které jsou aplikovány nejen v Grazu, můžeme dělit podle kritérií. V zóně Graz-West bylo aplikováno urbanistické členění na klastry. Pro každý klastr bylo na počátku jasně definováno, co je zde možné stavět a za jakých podmínek. Systém těchto klastrů se velmi osvědčil a mohla zde být použita další metoda „krok za krokem“, kdy se jednotlivé části této lokality mohou transformovat postupně, uceleně a $\mathrm{v}$ předem daném měřítku. Jednotlivé klastry byly dále děleny a byla řešena dopravní infrastruktura se zaměřením na potlačení individuální dopravy. Také zde se samozřejmostí pracují s modrou (vodní) a zelenou (parky, zeleň) infrastrukturou. (Graz West: Ein Stadtteil im Aufbruch, 1998)

Do Smart City řadíme projekty Plus Energy Network Reininghaus Süd, Waagner Biro a Reininghaus Goes Smart. Dalším bodem Smart city je sdílení informací a participace občanů. Tato složka je nedílnou součástí plánovacího procesu. Celý systém plánování a komunikace byl zajištěn externí organizací CityLAB Graz. CityLAB působí jako výzkumná a inovativní platforma v záležitostech týkajících se kvality městského života. CityLAB Graz vytváŕí prostor pro nápady a propaguje interdisciplinární, otevřenou diskuzi zúčastněných subjektů. (Stadtlaborgraz, 2016) 
Další organizací je Creative Industries Styria, jejímž úkolem je koordinovat kreativní služby a rozšiřovat postavení kreativního průmyslu v kontextu štýrské ekonomiky. Kreativní průmysl byl definován štýrskou zemskou vládou jako jedna z klíčových kompetencí Štýrska a ukotven v ekonomické strategii Styria 2020 a v ekonomické strategii města. (Creative Industries Styria, 2016)

Smart City se také zaměřuje na využívání alternativních zdrojů energie a obnovitelných zdrojů a na snížení emisí. Je to lokalita výzkumu. Zkoušejí se zde nové postupy a metody a jejich aplikace. Nachází se zde Green Tech Valley, které je domovem 200 firem a výzkumných institucí v oblasti zelených technologií v rámci klastru Green Tech. (Greentech, 2016)

Byl zde vytvořen pilotní projekt ECR - Plus Energy Network Reininghaus Süd. Tento urbanistický celek se nachází na plochách bývalého pivovaru - oblast Graz-West. Při realizaci projektu fungovala mezioborová spolupráce (výzkum + věda + aplikace). Tento energetický celek je soběstačný.

Další lokalitou, která se začíná realizovat, je Smart City Graz Waagner - Biro. Toto území bude zcela energeticky soběstačné. Nachází se v oblasti Graz West, kde je znečištěná zemina, a proto zde není možné stavět pod zem. Součástí tohoto území je Helmut List Halle, vedle níž se nachází Věž vědy, kde byly poprvé použity průhledné solární panely jako fasáda budovy. Tato oblast bude sloužit jako demonstrační oblast. (Smart City Graz, 2016)

Třetí, v současné době připravovanou, lokalitou je Reininghaus Goes Smart. Tato lokalita navazuje na lokalitu projektu ECR - Plus Energy Network Reininghaus Süd. Architektonický ateliér, který toto území řešil, vytvořil projekt s různými typy veřejných prostorů a zaměřil se na kompaktní struktury bloků a $\mathrm{k}$ tomu $\mathrm{v}$ kontrastu struktury věží. Jednotlivé budovy budou schopny reagovat na potřeby trhu.

\section{Vize Grazu v roce 2050}

Město kompaktní a dynamické s promixovanou strukturou. Město s atraktivními otevřenými prostory a s nejvyšší kvalitou života. Město s nulovými emisemi za pomoci všech městských strategií a technologií. (Smart City Graz, 2016); (Stadtteilmanagement, 2016)

Na základě pozorování zmíněných lokalit můžeme říct, že není důležité, jak byly transformace těchto lokalit úspěšné, jde zde hlavně o jednotlivé procesy. Na začátku si musíme pokládat otázky: Co chceme transformovat? Jakou vizi chceme lokalitě dát? Kde seženeme finance? Jak vytvoříme sounáležitost s místem pro jeho obyvatele? 
V Grazu nalézáme odpovědi na to, jak procesy utvářely lokality. A jaké podpůrné aktivity, fondy a organizace se na procesech podílely. Proto tyto lokality a programy, pomocí nichž byly vytvořeny, mohou být nejen inspirací, ale i manuálem, jak pracovat s lokalitami v Brně.

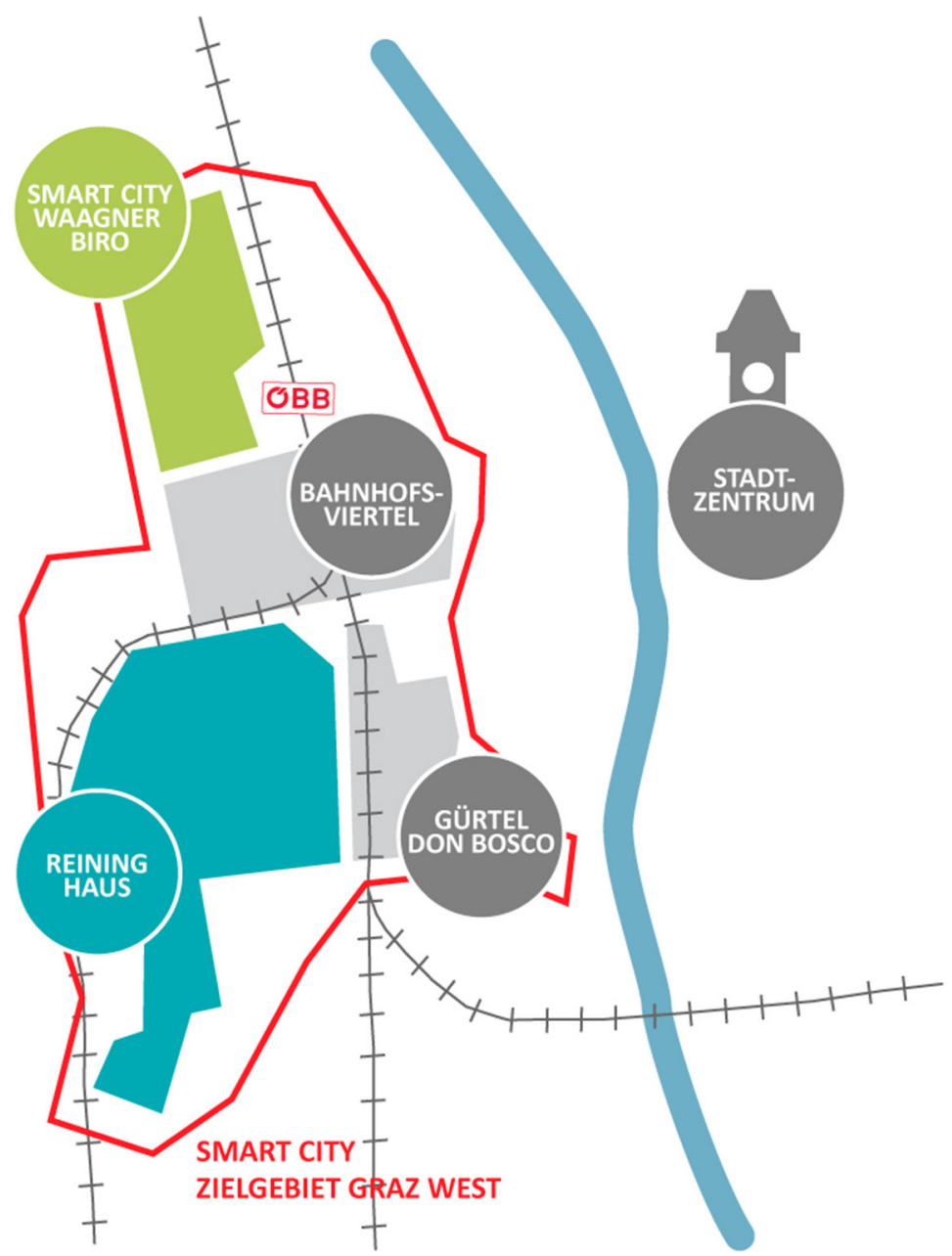

Obr. 1. Etapy (Zdroj: http://www.smartcitygraz.at/wordpress/wp-content/uploads/2013/10/SCG-Quartier-map-021_bearb-NUS141022.jpg) 


\section{Prameny}

Štýrský Hradec. 2015. Wikipedia: the free encyclopedia [online]. San Francisco (CA): Wikimedia Foundation [cit. 2016-01-20]. Dostupné z: https://cs.wikipedia.org/ wiki/Štýrský_Hradec

ARANDJELOVIC, Biljana. 2015. Graz, UNESCO City of Design and Historical Heritage. Cities [online]. Elsevier Ltd., 43, 78-91 [cit. 2016-03-04]. DOI: 10.1016/j. cities.2014.11.014. ISSN 02642751.

MAGISTRAT GRAZ. 1998. Urban Graz. Graz.

Graz West: Ein Stadtteil im aufbruch. 1998. Graz: Konsortium Graz- West.

Urban Graz - West newsletter der programmleitung: newsletter 4. 2005. 1. Graz: Magistrat Graz. ISBN 3-901672-08-7.

Stadtlaborgraz [online].2016. Graz [cit. 2016-09-10]. Dostupné http://www.stadtlaborgraz.at/index.php/en/thecitylabis

Creative industries styria [online]. 2016. Graz [cit. 2016-09-10]. Dostupné z http:// www.cis.at/de/aboutus/creative-industries-styria

Greentech [online]. 2016. Graz [cit. 2016-09-10]. Dostupné z https://www.greentech.at/ Smart city Graz.2016 Dostupné z http://www.smartcitygraz.at/

Stadtteilmanagement[online]. 2016. Dostupné z: www.stadtentwicklung.graz.at 